\title{
TANTANGAN MASYARAKAT MARITIM PASCA TSUNAMI DI PESANGGARAN DESA PESANGGARAN BANYUWANGI
}

\author{
Tian Fitriara Huda ${ }^{1}$, Akhmad Touwil Firdaus ${ }^{2}$ \\ Dosen FKIP Universitas PGRI Banyuwangi ${ }^{1}$, Dosen Hukum Universitas Bakti Indonesia ${ }^{2}$ \\ tianfitriarahuda@gmail.com \\ akhmadtouwilfirdaus@gmail.com
}

\begin{abstract}
Abstrak
Banyuwangi sebagai bagian ujung timur dari Pulau Jawa dengan memiliki nuansa alam maritim yang unik dan menarik terutama karena posisinya di wilayah Laut Pantai Selatan. Meskipun nilai positif tersebut juga memiliki dampak negatif akibat kondisi geografis Indonesia yang terletak di kawasan rawan dengan gempa dan tsunami, hal ini merupakan akibat adanya tiga lempeng dasar laut, yakni Lempeng Eurasia, Lempeng Indo Australia dan Lempeng Pasifik.Bencana tsunami akhirnya datang di Banyuwangi pada 3 Juni 1994 dengan dampak besar bagi kondisi sosial ekonomi masyarakat maritim, terutama di kawasan pesisir pantai selatan Banyuwangi yaitu Kecamatan Pesanggaran. Hutan dan pantai-pantai yang ada di Kecamatan Pesanggaran masih alami dan sangat menarik serta memiliki ciri khas masing-masing dari setiap tempatnya. Setelah bencana, masyarakat mengutamakan kondisi sebagai awal perubahannya. Namun perubahan dengan tambahan bantuan dari Pemerintah Kabupaten Banyuwangi, belum juga memiliki dampak untuk menguatkan kondisi sosial ekonomi masyarakat maritim di Dusun. Penelitian ini untuk mengetahui tentang kondisi sosial ekonomi masyarakat maritim di Desa Pesanggaran dengan tempat yang unik dan menarik setelah bencana tsunami hingga sekarang. Hasil kajian digunakan menjadi acuan dan dasar pertimbangan bagi masyarakat maritim di Dusun Ringinagung dan Pemerintah Kabupaten Banyuwangi untuk mengadakan sejumlah pembaharuan sosial ekonomi terkait dengan dunia pariwisata. Penilitian ini menggunakan pendekatan kualitatif dengan rancangan studi kasus yaitu memakai perspektif fenomenologis. Pemilihan responden menggunakan snow ball, dimana sampel dalam penelitian ini adalah masyarakat maritim yang berada di Kecamatan Pesanggaran Kabupaten Banyuwangi. Metode yang digunakan dalam analisis data yaitu kualitatif deskriptif. Hasil penelitian akan menjadi rekomendasi untuk pemahaman mendalam tentang kondisi sosial ekonomi masyarakat melalui pemanfaatan lingkungan alam di sekitarnya dan peran pemerintah dalam pemberian kebijakan baru bagi masyarakat maritim di pesisir pantai selatan Banyuwangi.
\end{abstract}

Kata Kunci : Maritim, pascatsunami, pesanggaran 


\begin{abstract}
Banyuwangi as the eastern end of the island of Java with its unique and interesting maritime natural nuance mainly due to its position in the South Coast Sea region. Although this positive value also has a negative impact due to Indonesia's geographical conditions located in areas prone to earthquakes and tsunamis, this is a result of the three seabed plates, namely the Eurasian Plate, the Indo Australia Plate and the Pacific Plate. The tsunami disaster finally came to Banyuwangi June 3, 1994 with a major impact on the socio-economic conditions of the maritime community, especially in the southern coastal area of Banyuwangi, namely Pesanggaran Subdistrict. Forests and beaches in Kecamatan Pesanggaran are still natural and very interesting and have the characteristics of each of them. After the disaster, the community prioritizes conditions as the beginning of the change. However, changes with additional assistance from the Banyuwangi District Government have not yet had an impact to strengthen the socio-economic conditions of the maritime community in Hamlet. This research is to find out about the socio-economic conditions of the maritime community in Pesanggaran Village with a unique and interesting place after the tsunami disaster until now. The results of the study are used as a reference and basis for consideration for the maritime community in the Ringinagung Village and the Banyuwangi Regency Government to hold a number of socio-economic reforms related to the world of tourism. This research uses a qualitative approach with a case study design that uses a phenomenological perspective. The selection of respondents using snow ball, where the sample in this study is the maritime community located in Pesanggaran Subdistrict, Banyuwangi Regency. The method used in data analysis is descriptive qualitative. The results of the study will be a recommendation for an in-depth understanding of the socio-economic conditions of the community through the use of the surrounding natural environment and the role of the government in granting new policies to the maritime community on the southern coast of Banyuwangi.
\end{abstract}

Keywords: Maritime, post-tsunami, Pesanggaran

\section{Latar Belakang}

Indonesia merupakan salah satu negara terluas di dunia dengan ribuan pulau yang masuk dalam wilayahnya memberikan cerminan kuat tentang posisinya sebagai negeri maritim terutama berada diantara dua samudera, yakni Samudera Hindia dan Samudera Pasifik. Sebagian besar penduduknya merupakan nelayan, pedagang serta para pelaku pemanfaatan hasil laut yang sangat melimpah ruah dengan luasnya wilayah laut di Indonesia. Sebagai negara luas dan penuh dengan segala keunikannya Indonesia memiliki 
beberapa hal negatif juga yang memberikan dampak bagi masyarakatnya terutama bagi penduduk di wilayah pesisir pantai, hal ini terlihat dari letak geologisnya yang berada di antara tiga lempeng litosfer yakni Lempeng IndoAustralia, Lempeng Eurasia dan Lempeng Pasifik. Akibat letak tersebut dapat memberikan dampak berupa bencana alam yang besar dan cukup berbahaya terutama gempa dan tsunami.

Banyuwangi sebagai bagian ujung timur dari Pulau Jawa memiliki nuansa alam unik dan menarik di pesisirnya yang merupakan wilayah dari Laut Pantai Selatan. Nuansa kehidupan masyarakat maritim di wilayah selatan Kabupaten Banyuwangi cenderung lebih mengalir kebudayaan Suku Jawa, hal ini ditandai dengan mayoritas penduduk adalah Suku Jawa serta budaya-budaya kunonya hingga sekarang masih dilaksanakan salah satunya adalah Petik Laut. Pesanggaran sebagai kecamatan bagian selatan dari Kabupaten Banyuwangi juga merupakan wilayah masyarakat maritim yang cukup terkenal dengan segala keindahan tempat-tempat wisatanya. Meskipun menjadi wilayah yang cukup besar dengan segala hasilnya namun sebagai bagian dari Negara Indonesia, Pesanggaran juga pernah mengalami dampak negatif letak geologis yakni tsunami.

Bencana tsunami pernah terjadi di pantai selatan Banyuwangi pada 3 Juni 1994 dengan kekuatan 7,8 SR serta kecepatan gelombang dari 400-600 $\mathrm{KM} / \mathrm{J}$ am yang mengakibatkan sekitar 210 orang meninggal dan 2000 rumah hancur karena ketinggian ombak yang datang ke pesisir pantai mencapai $14 \mathrm{~m}$ (pendapat I Gede Agus Purbawa, dalam wawancara di Kantor BMKG Banyuwangi pada 27 Mei 2017). Hal inilah awal dari kemunduran kondisi ekonomi masyarakat maritim di Kabupaten Banyuwangi. Daerah-daerah tersebut terdiri dari Muncar, Grajagan dan Pesanggaran. Namun dari tsunami tersebut dampak terkuatnya adalah di daerah Pesanggaran.

Pemerintah Kabupaten Banyuwangi pada masa pasca tsunami tersebut memberikan beberapa bantuan melalui upaya pemberian semacam pembelajaran mulai dari Bahasa Inggris, surfing, usaha rumah makan, homestay, hingga pemasaran nasional dan internasional untuk kawasan wisata melalui akun Pemerintah Kabupaten Banyuwangi 
serta lain-lainnya. Namun segala hal tersebut belum juga memberikan dampak positif yang besar bagi masyarakat maritim di kawasan Pesisir Pantai Selatan. Berdasarkan hal tersebut, penelitian ini hendak mengkaji berkaitan dengan tantangan sosial ekonomi masyarakat Desa Pesanggaran Kabupaten Banyuwangi pasca tsunami di tahun 1994.

\section{Metode Penelitian}

Penelitian ini menggunakan pendekatan kualitatif fenomenologis, karena sesuai dengan tujuan penelitian yakni untuk mempelajari secara rinci fenomena sosial ekonomi yang terjadi secara nyata dan apa adanya. Sejalan dengan hal itu deskripsi fenomenologis bisa dibedakan ke dalam tiga fase yaitu: (1) mengintuisi, (2) menganalisis, (3) menjabarkan secara fenomenologis. Setelah mendapatkan temuan-temuan dalam penelitian ini kemudian akan diproses dalam model Miles dan Huberman yaitu: a. proses reduksi data, b. proses penyajian data, c. verifikasi data, d. proses menarik kesimpulan. Adapun yang menjadi sumber data penelitian ini adalah sebagai berikut: a). Sumber data primer, yaitu sumber data yang dijadikan sebagai data pokok dalam penelitian ini, yang diperoleh dari observasi dan interview. b). Sumber data sekunder, sumber data sekunder adalah data pelengkap sebagai pendukung dalam penelitian ini yang diperoleh dari buku dan jurnal.

Responden dalam penelitian ini adalah informan yang dipandang dapat memberi yang dibutuhkan dalam penelitian seperti peran masyarakat dalam memanfaatkan situasi dan kondisi dari kemegahan alam yang sangat menarik, serta pihak lain yang terkait dalam pengumpulan data penelitian ini. Informan ditetapkan dengan cara snow ball yaitu teknik penentuan sampel yang mula- mula jumlahnya kecil kemudian membesar mengikuti fenomena di lokasi penelitian. Sebelum penelitian dilakukan, terlebih dahulu menentukan mengenai subjek yang diteliti yaitu lokasi letak dimana penelitian akan dilakukan untuk memperoleh data atau informasi yang berkaitan dengan permasalahan penelitian. Adapun yang menjadi subjek dalam penelitian ini adalah masyarakat maritim di Desa Pesanggaran 
Kecamatan Pesanggaran Kabupaten Banyuwangi.

Memperoleh data dan informasi yang objektif di lapangan dan instrumen dalam Metode Penelitian Kualitatif adalah si peneliti sendiri, umumnya dengan observasi partisipan dan analisis dilakukan sejak penelitian dimulai sampai selesai. Sumber data utama dalam penelitian ini adalah kata- kata dan tingkah laku (tindakan) selebihnya adalah tambahan data seperti dokumen dan lainlain dan pengumpulan datanya dilakukan secara langsung. Peneliti menggunakan observasi, interview dan dokumentasi. Data penelitian dianalisa secara kualitatif deskriptif dengan pendekatan fenomenologi.

\section{Kajian Teori dan Konsep Penelitian}

\section{A. Maritim}

Maritim cenderung diarahkan sebagai nelayan dan kapal, dengan kehidupan yang selalu dikaitkan dengan perdagangan laut. Sedangkan menurut Anshoriy dan Arbaningsih Maritim
Indonesia tidak sebatas itu saja, melainkan mencakup makna lebih luas yakni wilayah kesatuan laut dan pulau secara utuh yang perlu dipertahankan oleh negara (2008). Sehingga bisa diartikan bahwa perkumpulan manusia yang hidup di wilayah pulau dan laut yang menjadi kesatuan dari negaranya.

\section{B. Pasca Tsunami}

Tsunami menurut BNPB adalah serangkaian gelombang ombak laut raksasa yang timbul akibat pergeseran di dasar laut akibat gempa bumi (alamat web). Gelombang ombak besar dan tinggi yang menghantam daratan memberikan dampak besar karena menimbulkan kekacauan serta kerusakan bagi penduduk dan alam di wilayah pesisir pantai mulai dari tempat tinggal, peralatan kehidupan dan peralatan pekerjaan. Dengan adanya dampak dari bencana tsunami memberikan dorongan bagi pemerintah untuk melakukan pengelolaan ulang bagi kondisi wilayahnya menjadi lebih baik lagi.

\section{Pesanggaran}

Pesanggaran merupakan sebuah Pemeritahan Kecamatan bagian selatan 
dari Kabupaten Banyuwangi, dengan jarak sekitar 60-62 KM dari pusat kabupaten. Dengan kondisi alam yang indah dan pantai yang menarik serta lingkungan bersih, tentu bisa dikatakan bahwa di Dusun Ringinagung memiliki banyak peluang usaha untuk meningkatkan ekonomi yang tentu bisa karena di kawasan maritim tersebut ada banyak potensi melalui ciri khasnya masingmasing. Hal ini senada dengan pernyataan Harini bahwa segala hal berkaitan dengan alam termasuk fenomenanya bisa menjadi sebuah peluang (2010).

\section{Kerangka Konsep Penelitian}

Banyuwangi dengan perkembangan ekonominya yang meningkat dari tahun ke tahun memberikan sebuah makna peluang kesejahteraan masyarakat juga bisa turut membaik. Terlihat dengan semakin ramai para wisatawan baik dari dalam maupun luar negeri datang untuk menikmati tempat wisata alam yang masih alami, terutama kawasan gunung serta kawahnya, hutan dan pesisir pantai di Laut Selatan Pulau Jawa. Hal ini telah membaik jika melihat masa lalu dari Kabupaten Banyuwangi yang pernah meredup akibat bencana tsunami, peran pemerintah melalui pembangunan baru sebagai awal munculnya perkembangannya. Namun masih belum mampu memberikan dampak kuat bagi masyarakat pinggiran di kawasan maritim, sehingga masih memerlukan hal baru di kawasan tersebut melalui peran pemerintah, masyarakat dan bagian kepariwisataan demi meningkatkan kesejahteraan masyarakat

\section{DAFTAR PUSTAKA}

Anshoriy dan Arbaningsih. 2008. Negara Maritim Nusantara Jejak Sejarah yang Terhapus. Yogyakarta: Tiara Wancana BMKG. 2017. Badan Meteorologi, Klimatologi dan Geofisika Wilayah 3 Denpasar http://balai3. denpasar.bmkg.go.id/tentang-gempa diunduh pada 13 Juni 2017.

Zamzami dan Hendrawati. 2014. Jurnal Antropologi Vol 16 No 1. Kearifan Budaya Lokal Masyarakat Maritim untuk Upaya Mitigasi Bencana di Sumatera Barat. FISIP 